\title{
Phenotypic Characteristics of Commercial Layer Strains, ISA Brown and Hisex Brown
}

\author{
Islam $\mathrm{S}^{1^{*}}$, Bari $\mathrm{MS}^{2}$, Moni $\mathrm{SP}^{3}$, Siddiqe $\mathrm{MZF}^{4}$, $\mathrm{Uddin}^{\mathrm{M}} \mathrm{H}^{5}$ and Miazi $\mathrm{OF}^{5}$ \\ ${ }^{1}$ Department of Medicine and Surgery, ${ }^{2}$ Department of Dairy and Poultry Science, ${ }^{3}$ Department of Physiology, \\ Biochemistry and Pharmacology, ${ }^{5}$ Department of Genetics and Animal Breeding, Faculty of Veterinary \\ Medicine, Chittagong Veterinary and Animal Sciences University, Khulshi, Chittagong-4225 \\ ${ }^{4}$ Department of Physiology, Faculty of Veterinary science, Bangladesh Agricultural University, Mymensingh, \\ Bangladesh
}

[Received: May 05, 2015; Accepted: August 04, 2015]

\begin{abstract}
The study was conducted to observe and compare the phenotypic characteristics of ISA brown and Hisex brown commercial layer strains. A total of 200 birds were examined out of 36000 in a commercial layer farms at Chandonysh upazila (sub-district) of Chittagong district, Bangladesh during the period of July to December, 2013. Observable difference was found in several phenotypic characteristics like plumage, beak, shank, egg, comb color and comb type between ISA brown and Hisex brown. In ISA brown shank length (cm), egg weight (gm) and body weight $(\mathrm{gm})$ was $3.32 \pm 0.01,59.44 \pm 0.47$ and $1846.60 \pm 11.18$ respectively where in case of Hisex brown it was $3.11 \pm 0.00$, $55.82 \pm 0.45$ and $1769.10 \pm 33.90$. Significant $(\mathrm{P}<0.05)$ difference was found in shank length $(\mathrm{cm})$, egg weight $(\mathrm{gm})$ and body weight $(\mathrm{gm})$. In ISA brown beak length and age at first lay was $2.02 \pm 0.01$ and $141 \pm 0.51$ respectively, On the other hand for Hisex brown, it was $2.02 \pm 0.01$ and $141 \pm 0.58$. There was no Significant $(\mathrm{P}>0.05)$ difference between the strains in respect of shank length, egg weight and body weight. Some innate characteristics of studied strains differentiate them and any improvement program of commercial layer strains should be incorporate production objectives and trait performance of the society.
\end{abstract}

Key words: Chandonysh, Commercial layer, Innate character, Phenotypic character, Strain.

\section{INTRODUCTION}

Poultry is by far the largest livestock group and has been estimated to be about 252.3 million consisting of chickens, ducks and pigeons in Bangladesh ${ }^{[1]}$. The species of chicken is the main constituents of poultry population ${ }^{[2,3]}$.

Malnutrition is an important and common phenomenon in the developing world, an increased demand for quality protein is being seen in such countries. To fulfill these demands, there is a greatest increase in the production of poultry and pigs ${ }^{[4]}$. Out of which, poultry play important role to fulfill the animal-source food ${ }^{[5,6]}$. In Bangladesh, around $9 \%$ of total protein for human consumption comes from livestock ${ }^{[7]}$ and Poultry contribute $30 \%$ of animal protein and will increase to $40 \%$ within $2015^{[8]}$.

In Bangladesh about 150 hatcheries have been producing around 4.56 million of day old chicks (DOC) per week. About 70,000 commercial layer farms supplying 4,056 millions of table eggs per year [7]. In the year of 2007-2008 broiler farms was $36.97 \%$, layer farms, $42.69 \%$; hatchery, $9.83 \%$; duck, $2.24 \%$; and mixed farm, $8.28 \%$ from Tk. 98253 million ${ }^{[9]}$.

Only rural people of Bangladesh rear indigenous chicken, but around $53 \%$ farm reared commercial chicken, $6 \%$ are mixed farm and rest of farm rear other types of poultry [9]. Productivity of local chickens is poor in the tropics that attributed by low genetic potential, feed problems and diseases ${ }^{[10,11]}$. Compared to their modern counterparts indigenous chickens are generally poor producers of eggs and meat. Consequently, they are being replaced by commercial strains in many developing countries ${ }^{[12]}$. Bangladesh is blessed with several commercial layer chicken strains distributed in different agroecologies. Their widespread distribution in the villages demonstrates the importance of these small and easily managed farm animals.

Among different commercial layer strains, Hisex brown and ISA brown are usually preferred by the farmer due to their high production and their innate characteristics. Also, social cultures and believes of most of the rural community have been highly attracted by these morphological variations of the birds in Bangladesh.

Above $75 \%$ of protein and $78 \%$ of meat are being produced by scavenging system. Most of the poultry product in Bangladesh is dominated by scavenging indigenous chicken. Indigenous chicken usually providing both egg and meat for farmers ${ }^{[13]}$. In scavenging system poultry are reared with low quality feed and their productivity is very low and irregular ${ }^{[14]}$. So with a view to meeting the protein demand within the short period of time there has been established shift policy of farm on the basis of commercial farm policy in Bangladesh those are operated under intensive management. In these farms poultries are reared with scientific poultry ration ${ }^{[13]}$.

A good commercial layer farm management is required for optimum growth and result in high egg production ${ }^{[15]}$. Around $75 \%$ of commercial layer farm are raised in cage system all over the world ${ }^{[16]}$. 
Egg production is the most important index of performance of commercial layer business, because of that its accounts for $90 \%$ of the income from the enterprise ${ }^{[17]}$. The commercial layer usually come in production around 19 weeks of age, rises sharply to a peak at about 26 to 27 weeks of age and then declines gradually. It is the common practice to replace old bird at 72 to76 weeks of age ${ }^{[18]}$.

Age at sexual maturity is an important trait from economic point of view. The age in days of starting lay is important not only for its first year production but also because the earlier life that a pullet start lying, the sooner she produces revenue ${ }^{[19]}$.

Age and weight at sexual maturity are mainly influenced by feed consumption, lighting schedule, length of daylight and environmental factors ${ }^{[20]}$. Age at sexual maturity is also influenced by pronounced sexual effect ${ }^{[21]}$.

To fulfill demand of protein we need huge production of chicken egg through intensive farming system with high yielding poultry breed or strain. The growth and automation of commercial egg manufacturing industry have developed quickly and progressed further than other types of livestock production during a period of only about last two decades in Bangladesh ${ }^{[13]}$.

Variations within and between breeds from which the strain come are important for improvement of commercial layer chickens to meet human needs. Such variations among individuals or groups of chickens give good resource opportunity for breeding and selection.

In Bangladesh the phenotypic and genetic constitution of the commercial layer chicken strain is very smallest. So available information about commercial layer chicken strain in Bangladesh is scanty on the basis of characterization and description.

However, there is a no comprehensive work to reviewing these and other related information and this is the first step to identify the phenotypic characteristics of layer strains in Bangladesh. Thereby, reviewing sensible findings on these chicken layer strain production and their innate characteristics seem to be a milestone area to deliver synthesized information to the beneficiaries. Moreover, reviewing the innate characteristics of Hisex and Isa brown chicken layer strains will contribute to the future plans of conservation and improving chicken production in the country. Based on this outlined background, the present study was conducted to compare phenotypic characters between Isa brown and Hisex brown.

\section{MATERIALS AND METHODS}

\section{Study area and period of study}

The study was conducted on commercial layer farm at Chandonysh upazila, Bangladesh. This area is located in the south-eastern region of Bangladesh at 22.2438 latitude and 92.0126 longitude. It is a part of the Chittagong Division. The duration of the study was six months from July to December, 2013.

\section{Study population}

The present study was conducted on 36000 layer strains of ISA brown and Hisex brown reared in a commercial poultry farm. A total of 200 birds were examined. They reared Hisex and ISA brown in ten shed and in five shed birds are reared in cage system and in another five sheds' birds are reared in deep litter system. Among ten shed, five sheds used for ISA brown and five sheds for Hisex brown. They have separate shed for rearing day old chick from brooding to pullet. In brooding shed, they provided feed adlibitum which contains $21 \% \mathrm{CP}$ and 2900 $\mathrm{kcal} \mathrm{ME} / \mathrm{kg}$ up to 8 weeks and $16 \% \mathrm{CP}$ and 2650 $\mathrm{kcal} \mathrm{ME} / \mathrm{kg}$ up to 18 weeks and in layer $17 \% \mathrm{CP}$ and $2750 \mathrm{kcal} \mathrm{ME} / \mathrm{kg}$ up to 72 weeks. The birds were vaccinated against Mareks, Newcastle, Fowl cholera, chicken pox and Gumboro diseases.

\section{Data collection}

The necessary data of related parameters were collected from record book of the poultry farm. Twenty birds were randomly selected from each shed and the following data were collected during the period of study by a previously structured questionnaire; (One hundred Hisex and one hundred ISA brown). Data were collected on the following parameters:

Beak length $(\mathrm{cm})$ and shank length $(\mathrm{cm})$ were determined by using measuring tape, where egg weight $(\mathrm{gm})$ and body weight $(\mathrm{gm})$ were determined by using digital balance. Other non-measurable data were collected by eye estimation like plumage color, beak color, shank color, egg color, and comb color and comb type, The age at first lay was calculated as duration of days between day old chicks (DOC) to start of egg laying.

\section{Housing}

The housing system was open sided for layer and closed house for brooding chick. In case brooding each chick guard contains 1200 chicks where space was 720square feet, contains electric brooder or gas brooder. It is increased according to age and up to 16 weeks of age.

\section{Watering}

For the prevention of diseases fresh and clean water were supplied to bird and each 75 birds need one round drinker and after 3 days later used nipple drinker (one nipple drinker for 8 to 10 birds) with round drinker.

\section{Feeding and feeder}

The experimental farm supplied feed to Day old chick (DOC) on especial flat feeder for 2 days. They provide linear feeder @ $2.5 \mathrm{~cm} / \mathrm{bird}$. The starter rations start after24 hours of arrival and contained CP 19 to 20\%, ME 2950/kg, lysine 1.07, and methionine 0.43 to $0.54 \%$. Adlibitum feeding was allowed for 3 weeks. Then weighing which compared with guide line.

\section{Lighting}

Lighting schedule followed in this farm is given below in table. 


\section{Data analysis}

The obtained information was imported, stored and coded accordingly using Microsoft Excel, 2007 for analysis. Then the data were imported in SPSS v16 statistical software. Descriptive analysis was done of the data followed by compare means (one way ANOVA) was done for suitable variables
In ISA brown and Hisex brown, Shank length $(\mathrm{cm})$ was found $3.32 \pm 0.01$ and $3.11 \pm 0.00$ respectively (Table 2) and there was significant $(\mathrm{P}<0.05)$ difference between the strain which is nearly similar to Olawunmi et al ${ }^{[22]}$.

The beak length $(\mathrm{cm})$ of ISA brown and Hisex brown strains was $2.02 \pm 0.01$.ISA brown and Hisex brown is insignificantly $(\mathrm{P}>0.05)$ dissimilar in beak length

Table: 1 lighting schedule were @ watt/sq.ft

\begin{tabular}{ccc}
\hline Age/day/week & Light/day(in hour) & Watt/sq.ft \\
\hline 1-3day & 24 hours & 0.56 watt \\
4-6day & 23 hours & 0.50 watt \\
7-8day & 23 hours & 0.37 watt \\
1-2weeks & 23 hours & 0.25 watt \\
2-3weekas & 22 hours & 0.19 watt \\
$3-4$ weeks & 18 hours & 0.19 watt \\
$4-5$ & 16 hours & 0.19 watt \\
$5-6$ & 14 hours & 0.19 watt \\
$6-10$ & 13 hours & 0.19 watt \\
$11-18$ & 12 hours & 0.095 watt \\
$18-20$ & 11.30 hours & 0.019 watt \\
$20-21$ & 12 hours & 0.25 watt \\
$21-22$ & 12.30 hours & 0.25 watt \\
$22-23$ & 13 hours & 0.25 watt \\
$23-24$ & 13.30 hours & 0.25 watt \\
$24-25$ & 14 hours & 0.25 watt \\
$25-26$ & 14.30 hours & 0.25 watt \\
$\geq 26-27$ & 16 hours & 0.25 watt
\end{tabular}

\section{RESULTS AND DISCUSSION}

The study was conducted in commercial poultry farm of Chandonysh upazila under Chittagong district in Bangladesh. The parameters which are related to this study about ISA brown and Hisex brown commercial layer strains were collected by observing, handling, restraining and measuring of different phenotypic parameters.
(Table 2). This is might be due to debeaking practice of the farm like debeaking at same day.

Egg weight (gm) of ISA brown and Hisex brown was found $59.44 \pm 0.47$ and $55.82 \pm 0.45$ respectively (Table 2). Statistically significant $(\mathrm{P}<0.05)$ difference in egg weight of ISA brown and Hisex brown was found. This result was consistent with the recommended level of egg weight of ISA brown at age 24 weeks $(59.2 \mathrm{~g})$ which is provided by Hendrix

Table 2: Phenotypic traits of ISA brown and Hisex brown

\begin{tabular}{llll}
\hline Variable & Strain & Mean \pm SE & P - value \\
\hline Shank & ISA brown & $03.32 \pm 0.01$ & 0.000 \\
length $(\mathrm{cm})$ & Hisex brown & $03.11 \pm 0.00$ & \\
Beak length(cm) & ISA brown & $02.02 \pm 0.01$ & 0.533 \\
& Hisex brown & $02.02 \pm 0.01$ & 0.000 \\
Egg weight(gm) & ISA brown & $59.44 \pm 0.47$ & \\
& Hisex brown & $55.82 \pm 0.45$ & 0.834 \\
Age at first & ISA brown & $141.0 \pm 0.51$ & \\
lay(days) & Hisex brown & $141.0 \pm 0.58$ & 0.036 \\
Body & ISA brown & $1846.60 \pm 11.18$ & \\
weight(gm) & Hisex brown & $1769.10 \pm 33.90$ & \\
\hline
\end{tabular}


Genetic Company limited ${ }^{[23]}$ and Nagle et al ${ }^{[24]}$ was found 63.1g. In case of Hisex brown result was coincided with recommended level of egg weight at age 25 weeks $(55.5 \mathrm{~g})$ which is provided by Hendrix Genetic Company limited ${ }^{[22]}$ and Nagle et al ${ }^{[26]}$ was found $61.5 \mathrm{~g}$. Variation with Nagle et $\mathrm{al}^{[24]}$ might be due to age and manage mental variation.

The average of age at first laying of ISA brown was found $141 \pm 0.51$ days and in case of Hisex brown it was $141 \pm 0.58$ days (Table 2) which is nearly agreed by Kabir and Haque ${ }^{[13]}$. But Average age at first laying of ISA brown is insignificantly $(\mathrm{P}>0.05)$ dissimilar with Hisex brown. In ISA brown and Hisex brown, age at first laying was higher than recommended level of Hendrix Genetic Company limited ${ }^{[23]}$. Variation with company level might be due to difference in management of poultry.

The average body weight (gm)of ISA brown and Hisex brown was found $1846 \pm 11.18$ and $1769.10 \pm$ $33.90 \mathrm{~g}$ respectively(Table 2).In this study, the average body weight of ISA brown was found significantly $(\mathrm{P}<0.05)$ higher than Hisex brown. But in case of ISA brown, body weight was nearly agreed $(1854.9 \mathrm{~g})$ by Nagle et al ${ }^{[24]}$ and body weight is nearly similar to recommended level of Hendrix Genetic Company limited ${ }^{[23]}$ at 31 weeks of age. In case of Hisex brown, body weight is also nearly similar to Nagle et al ${ }^{[24]}$ and Hendrix Genetic Company limited ${ }^{[23]}$ at 23 weeks of age.

Brown colored feather, reddish colored and single type of comb; yellowish colored shank and beak; brownish colored egg shell was found in both strains. Similar result was reported for plumage color ${ }^{[23]}$, color and type of comb ${ }^{[25,23]}$; shank and beak color ${ }^{[26,23]}$; and egg shell color ${ }^{[23]}$ in Isa brown and Hisex brown layer strains by different researchers.

\section{CONCLUSION}

Population of commercial layer strain in Bangladesh is increasing. Chicken is only species that is expected to be found in village that serves as a source of income and nutrition. Therefore emphasis should be given from stakeholders (policy makers, research and development bodies) to increase chicken population. Bangladesh has diversified agro-ecologies that may be attributing for the presence of diversified phenotypic appearance of commercial layer strain. Most communities from different parts of a country have been attaching their social believes and life with such morphological characteristics of commercial layer chicken. This may create influences on the market values of poultry. Thus any breeding and improved production program of the commercial layer should therefore, incorporate the production objectives and trait performances of the society. By improving the approaches and traditional management of commercial layer, better performance always been achieved from these birds. Hence, these huge gene pool should be protected from genetic erosion and apply for improvement through scientific selection together along with technologies of genomics.

\section{REFERENCES}

1. Bangladesh Bureau of Statistics (BBS) (2009). Agriculture Sample Survey of Bangladesh 2005. Planning Division, Ministry of Planning. Government of the Peoples Republic of Bangladesh.

2. Gueye EF (2003). Production and consumption trends in Africa. World Poult. Sci. J. 19: 12-14.

3. Yami A, Dessie T (1997). The status of poultry research and development in Ethiopia. Proceedings of the 5th National Conference of Ethiopian Society of Animal Production (ESAP), May 15-17, 1997 Addis Ababa Ethi. pp: 40-60.

4. Mengesha M, Tamir B, Dessie MT (2008). Village chicken characteristics and their seasonal production situation in Jamma District, South Wollo, Ethiopia. J. Livest. Res. Rural. Dev. Vol. 20.

5. Food and Agriculture Organization (FAO) (2000). Statistical Database. Food and Agriculture Organization of the United Nations. Rome, Italy.

6. Permin A, Pedersen G (2010). Problems related to poultry production at village level. Proceedings of the Possibilities Smallholder Poultry Projects in Eastern and Southern Africa, May 22-25, Morogoro, Tanzania. pp: 65-69.

7. Directorate of Livestock Services (DLS) (2012). Annual report on livestock, Division of Livestock Statistics, Ministry of Fisheries And Livestock, Farmgate, Dhaka, Bangladesh. (MPADM_DLS draft 2).

8. International Food Policy Research Institute (IFPRI) (2000). www.cgiar.org/IFPRI.

9. Federal Parent Locator Service (FPLS) (2010). Office of Child Support Enforcement. (http://www.acf.hhs.gov/programs/css).

10. Yongolo MGS (1996). Epidemiology of Newcastle disease in village chickens in Tanzania. M.Sc. Thesis, Sokoine University of Agriculture, Tanzania.

11. Alexander DJ (2001). Newcastle disease. $B r$. Poultry. Sci. 42: 5-22.

12. Teklewold H, Dadi L, Yami A, Dana N (2006). Determinants of adoption of poultry technology: a double hurdle approach, Livestock Research for Rural Development, 18(3).

(http://www.cipav.org.co//rrd//rrd18/3/tek11804 0.htm).

13. Kabir F, Haque MT (2010). Study on production performance of ISA brown strain at Krishibid Firm ltd. Trishal. Mymensingh. Bd. Res. Pub. J. 3: 1039 - 1044.

14. Huque QME (1993). Current Status of Poultry Production and Marketing System In Bangladesh Agricultural Research Council, 
UAAID, Checchi and Company Consulting, Inc.

15. Samad MA (2005). Poultry Science and medicine, 1st edition, LEP publication, BAU campus, Mymensingh, Bangladesh.

16. North MO (1984). Commercial chicken production manual, 3rd edition. Avi publishing company, Inc, West port. C.T.

17. Oluyemi JA, Robert FA. (1979). Management and Housing of adult birds, in. Poultrry production in warmwet climates, pp.49-106.

18. Rahman M (2003). Growth poultry industry in Bangladesh: Poverty alleviation. And employment .Proceeding of the third international poultry show and seminar,February 28 to March 2, 2003, Held in Bangladesh China Friendship Conference Center(BCFCC), Sher-e-Bangla nagar, Dhaka. pp, 1-7.

19. Jull MA (1970). Poultry Breeding. Third edition. Jhon Wiley and Sons, New York, 26. pp. 285.

20. Morris IR, Fox S (1960). The use of listh to delay sexual maturity in pullets. Animal Breeding Abstract. 28: 458.

21. Eaton RC, Greene DH, Bioloke DH, Bioloke HI, Bethke RM (1961). Influence of season and age of sexual maturity on Broad Breasted Bronze Turkey. Poult. Sci. 40: 1399.

22. Olawunmi OO, Salako AE, Afuwape AA (2008). Morphometric Differentiation and
Asessment of Function of the Fulani and Yoruba Ecotype Indigenous Chickens of Nigeria. Int. J. Morp. 26(4): 975-980.

23. ISA Brown Management Guide. A Hendrix Genetic Company. www.HendrixGenetics.Com.

24. 23rd Annual Australian poultry science symposium. $19^{\text {th }}-22^{\text {nd }}$ February, 2014. The Poultry Research Foundation (University of Sydney) and The World's Poultry Science Association. Sydney, New South Wales.www.google.com/url?sa=t\&rct=j\&q=\&e $\mathrm{src}=\mathrm{s} \&$ source $=$ web $\& \mathrm{~cd}=2 \& \mathrm{cad}=\mathrm{rja} \& u a c t=8 \& \mathrm{v}$ ed=0CCsQFjAB\&url=http $\% 3 \mathrm{~A} \% 2 \mathrm{~F} \% 2 \mathrm{Fsydne}$ y.edu.au $\% 2$ Fvetscience $\% 2$ Fapss $\% 2$ Fdocument s\%2F2012\%2FAPSS2012Proceedings.pdf\&ei= kJIqVam5AdWPuASN34GQBw\&usg=AFQjC NGL64q1UMiPOZuz3UT5uEldE6g42A\&sig2 $=\mathrm{L} 1 \mathrm{wI}$-jaobSmqDDodIVZO3w

25. Halima H, Neser FWC, van Marle-Koster E (2007). Village based indigenous chicken production system in north-west Ethiopia.Trop. Anim. Health Prod.39: 189-197.

26. Guni FS, Katule AM (2013). Characterization of local chickens in selected districts of the Southern Highlands of Tanzania: I. Qualitative characters. Livestock Research for Rural Development. 9: 25. 